\title{
Effects of sodium bicarbonate injection on sensory and chemical qualities of rainbow trout during iced storage
}

\section{Sodyum bikarbonat enjeksiyonunun buzda depolanan gökkuşağı alabalığının duyusal ve kimyasal kalitesine etkisi}

\author{
Elif Tuğçe Aksun* • Bahar Karakaya Tokur
}

Department of Fishing and Fish Processing Technology, Faculty of Fisheries, Cukurova University, 01330 Balcali, Adana, Turkey ${ }^{*}$ Corresponding author: etaksun@cu.edu.tr

How to cite this paper:

Aksun E.T., Karakaya Tokur, B., 2014. Effects of sodium bicarbonate injection on sensory and chemical qualities of rainbow trout during iced storage. Ege J Fish Aqua Sci 31(2): 97-105. doi: 10.12714/egejfas.2014.31.2.06

\begin{abstract}
Özet: Bu çalışmada, gökkuşağı alabalığına hasat sonrasında farklı oranlarda sodyum bikarbonat (SBC) enjeksiyonun 21 günlük buzda depolama boyunca kalitesine etkileri araştırımışıı. Gökkuşağı alabalı̆ııın kalite değerlendirmeleri pH, toplam uçucu bazik azot (TVB-N, mg N/100 g), tuzda çözünür proteinler(SEP), Sodyum Dodesil Sülfat Poliakrilamit Jel Elektroforezi (SDS-PAGE) ve duyusal analizlerle belirlenmiştir. Sonuç olarak, SBC enjeksiyonuyla birlikte alabalıklarda $\mathrm{pH}$ değerleri yükselmiş ve TVB-N değerleri azalmıştır. Depolama süresi sonunda en düşük pH değeri $0.5 \mathrm{M} \mathrm{SBC}$ enjekte edilen grupta bulunurken; en yüksek pH değeri $1 \mathrm{M} \mathrm{SBC}$ enjekte edilen grupta bulunmuştur. Depolama süresi sonunda TVB-N değerleri açısından en yüksek değeri 31.17

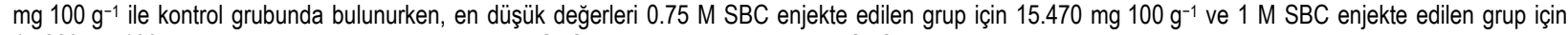

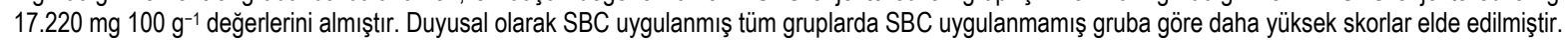

Anahtar kelimeler: Gökkuşağı alabalığı, sodyum bikarbonat, kalite, buzda depolama

Abstract: In this study, different concentrations of sodium bicarbonate (SBC) injection just after harvested was applied to enhance the qualities of trout during iced storage for 21 day. The quality of trout was evaluated using $\mathrm{pH}$, total volatile basic nitrogen (TVB- $\mathrm{N}, \mathrm{mg} \mathrm{N} / 100 \mathrm{~g}$ muscle), amount of salt- soluble protein (SEP), sodium dodecyl sulphate polyacrylamide gel electrophoresis (SDS-PAGE) and sensory analyses. In conclusion, the pH of trout muscle increased and TVB-N value decreased following treatment with SBC. At the end of storage the lowest $\mathrm{pH}$ value was obtained from $0.5 \mathrm{M} \mathrm{SBC}$ group, the highest ph value was obtained from 1M group. The highest TVB-N value was obtained for the control group with $31.17 \mathrm{mg} 100 \mathrm{~g}-1$ value, and the lower TVB-N value was obtained for $0.75 \mathrm{M} \mathrm{SBC}$ injected group with $15.470 \mathrm{mg} 100 \mathrm{~g}-1$ value and $1 \mathrm{M} \mathrm{SBC}$ injected with $17.220 \mathrm{mg} 100 \mathrm{~g}-1$ at the end of storage. Improvements were observed for all sensory attributes in all SBC- treated samples during storage.

Keywords: Rainbow trout, sodium bicarbonate, quality, iced storage

\section{INTRODUCTION}

Aquaculture has developed extensively over the last 30 years in all parts of the world. Rainbow trout is one of the most popular aquaculture fish species worldwide. It offers many advantages for commercial fisheries and the fish-processing industry in general. In Turkey, rainbow trout aquaculture accounts for $70 \%$ of the total national and international trade in farmed fish. According to the Turkey Statistical Institute, rainbow trout production has, increased from 86 thousand tons in 2010 to 129 thousand tons in 2013 (TÜIK 2014). Trout aquaculture has increased so rapidly, there is a need to identify ways to maintain consumer acceptability and extend the shelf life of the fish. Trout's storage quality is very important and especially sensitive to post-mortem changes which in turn are strongly influenced by processing and storage conditions. Due to having weak connective tissue and high enzyme activity, $\mathrm{pH}$ and water content, fish flesh in general is prone to undesirable degradative changes. Recently there has been intense research into methods that would increase the shelf life and overall quality of fish meat. Included among these methods; using of protective food additives is the mostly used to improve processing procedures.

Application of sodium bicarbonate has proven beneficial in the chicken and pork industries. In the case of broiler breast meat and porcine meat, deteriorative changes were significantly mitigated by pre- and post-mortem injection of sodium bicarbonate (SBC) (Sen et al. 2005; Yang et al. 2006). Offer and Trinick (1983) reported that the $\mathrm{pH}$ of meat muscle was increased by injection with sodium bicarbonate and that it improved drip loss and water-holding capacity, while reducing the tendency to shear which is caused by low 
$\mathrm{pH}$ and denaturation of myofibrils and sarcoplasmic proteins. Kauffman et al. (1998) investigated the ability of post-mortem SBC injection to address concerns in the pork industry about pale, soft and exudative (PSE) meat. Within 15 minutes after the death of the animal, they injected pork with a solution estimated to be approximately $10 \%$ of the tissue weight and containing $7 \%$ sodium chloride, and $0.2 \mathrm{M}$ or $0.4 \mathrm{M} \mathrm{SBC}$ These researchers reported that injection of pork with sodium chloride and SBC improved the colour of the meat, increased tissue $\mathrm{pH}$ and decreased drip loss. Yang et al. (2006) observed that SBC improved meat quality as assessed by muscle $\mathrm{pH}$, water-holding capacity, colour, drip loss, cooking loss and shear force. Sen et al. (2005) observed that treatment with tetrasodium pyrophosphate and sodium bicarbonate improved the colour and sensory attributes of preand post-chilled breast meat. Furthermore, SBC application inhibited the growth of Escherichia coli, Lactobacillus plantarum, Staphylococcus aureus, and Pseudomonas aeruginosa and yeasts in an agar-media model system (Corral et al. 2006). Bertram et al. (2008) obtained similar results as determined using their advanced microscopic analysis of pork marinate. Other in stigators have demonstrated that injection of sodium bicarbonate into pork decreases shear force and drip loss (Wynveen et al. 2001; Kaufmann et al. 1998).

Research regarding the injection of SBC in seafood processing has been more limited than in the chicken and pork industries. Åslı and Morkere (2011) injected SBC into salted cod fillets and found that SBC improved their textural and organoleptic properties.

In the present study, the effects of injection of different proportions of SBC on the changes in chemical and sensory quality parameters during ice storage were investigated.

\section{MATERIAL AND METHODS}

\section{Materials}

Rainbow trout (Oncorhynchus mykiss), 250-300 g, were purchased from a local trout farm in Adana. The time between harvesting and arrival of the fish at the laboratory was less than $2 \mathrm{~h}$, and they were kept in ice throughout transportation. Sodium bicarbonate manufactured by $\mathrm{Dr}$ Oetker was obtained from a local grocery.

\section{Methods}

\section{Injection of SBC in whole trout just after harvested}

Four different SBC solutions were prepared at concentrations of $0.25 \mathrm{M}, 0.50 \mathrm{M}, 0.75 \mathrm{M}$, and $1 \mathrm{M}$. The same volume of distillated water without SBC served as the control. Sample was divided five groups; each group consists of $75 \pm 5$ pieces fish. The fish from each group were netted out by hand and killed by a blow to the head after completion of the injection.In injection process, both sides of the fish body region were separated four equal parts and total of eight separate utility injection region were obtained. After injection, all samples were immediately stored in ice and transported to the laboratory.

\section{Sensory analysis}

For sensory analysis, to prepare the cooked fish sample, fish from each group were grilled at $180{ }^{\circ} \mathrm{C}$ for $20 \mathrm{~min}$. Three replicates of stored fish from each group were taken at regular intervals and assessed by a minimum of six trained panelists for their appearance, odour, flavour and texture using a hedonic scale from 9 to 1 according to the method of Paulus et al. (1979) with minor modification. A score of 9 represents 'very good quality', a score of 7-8, 'good quality', a score of 56 'acceptable', while a score of 1-4 being regarded as 'bad or unacceptable'.

\section{Chemical analyses}

$\mathrm{pH}$. The $\mathrm{pH}$ of rainbow trout was determined during ice storage using a pH meter ((Inolab pH 720, WTW 82362, Weiheim, Germany). The tissue was homogenized in distilled water in the ratio $1: 10 \quad(\mathrm{w} / \mathrm{v})$ immediately before measurements were made.

Total volatile basic nitrogen (TVB-N). The TVB-N content was determined according to the method of Antonocopoulus (1973) and expressed as mg TVB-N per 100 $\mathrm{g}$ rainbow trout muscle.

Salt Extractable Protein (SEP): Salt-soluble proteins (SEP). Soluble proteins were extracted according to the procedure of (Dyer et al.1950). One-half gram of $\mathrm{g}$ fish muscle was homogenized with $5 \% \mathrm{NaCl}$ solution using a homogenizer (Ultra-turrax, Ika T8, 1KA Labortechnik, Staufen, Germany) for $1 \mathrm{~min}$ at speed $5(20,000 \mathrm{rpm})$ in ice. Homogenate was then centrifuged at $5,000 \times \mathrm{g}$ at $4^{\circ} \mathrm{C}$ for 20 min using a Hettich Rotina $420 \mathrm{R}$ bench centrifuge (DJB Labcare Ltd., Buckinghamshire, UK). The salt-soluble proteins and SDS-PAGE were recovered in the supernatant. Lowry et al. (1951) was used to estimate the protein concentration in the resulting supernatants using bovine albumin as a protein standard. Salt extractable protein was expressed as the concentration of salt extractable protein $(\mathrm{mg} / \mathrm{ml})$.

Sodium dodecyl sulfate (SDS)-polyacrylamide gel electrophoresis (PAGE). SDS-PAGE was used to monitor polymerization and fragmentation of proteins using a BioRad Mini vertical gel electrophoresis. SDS-PAGE was performed in a $10 \%(\mathrm{w} / \mathrm{v})$ resolving gel and $4 \%(\mathrm{w} / \mathrm{v})$ stacking gel run at 200 $\mathrm{V}$ for $45 \mathrm{~min}$ (Laemmli, 1970). Gels were stained overnight with $0.025 \%$ (w/v) Coomassie blue R-250 in 40\% aqueous methanol and $7 \%$ acetic acid. Destaining was achieved by sequential treatment of gels first with an aqueous solution consisting of $40 \%$ methanol and $7 \%$ acetic acid, followed by $5 \%$ aqueous methanol and $7 \%$ acetic acid, and finally distilled water. Protein molecular weight standards were obtained from Sigma Ltd. (St. Louis,MO) consisted of glyceraldehyde-3phosphate dehydrogenase, rabbit muscle $(36,000 \mathrm{kDa})$, ovalbumin, chicken egg $(45,000 \mathrm{kDa})$, glutamic dehydrogenase, bovine liver $(55,000 \mathrm{kDa})$, albumin, bovine 
serum $(66,000 \mathrm{kDa})$, phosphorylase $B$, rabbit muscle $(97,000$ $\mathrm{kDa}) \beta$-Galactosidase, $E$. coli (116,000 kDa), myosin, porcine heart $(200,000 \mathrm{kDa})$

\section{Statistical analyses}

SPSS for Windows software program (SPSS 18.0 for Windows ) was utilised to calculate analysis of variance (Anova) using the general linear models procedure. Duncan's multiple range test was used to determine significant differences between treatments at $95 \%$ confidence interval.
Sensory analyze was performed using non-parametric test and differences between in groups were evaluated analysis of variance. A p value of 0.05 ws considered significant.

\section{RESULTS AND DISCUSSION}

\section{Sensory evaluation}

The results of the sensory evaluation (color, odor, flavor, texture and general acceptability) in SBC injected groups are shown in Figure 1.
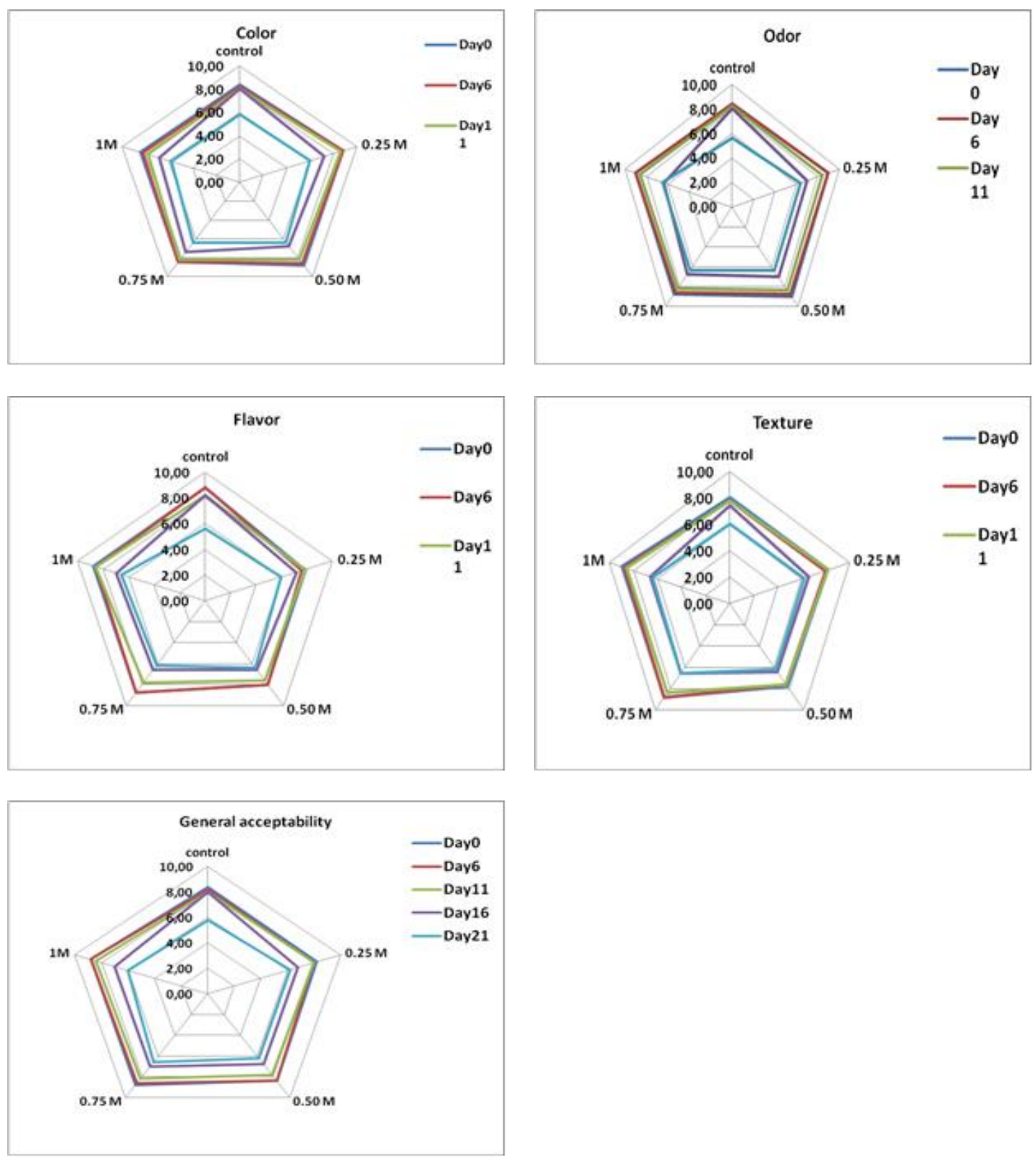

Figure 1. The effect of different concentrations of SBC injection on sensory attributes of whole trout during iced storage 
Up to day 16, sensory scores of all groups of SBC injected by means of color, odor, flavor, texture and genera acceptability were scored as "good quality" .However after 16 days of ice storage, the scores in all groups decreased significantly $(p<0.05)$.

The color values of whole trout during ice storage did not significantly affected by SBC injection ( $p>0.05)$. On the other hand, Wynveen et al. (2001) reported that SBC injection of pork improved color scores at the early post-mortem stage. Similarly, Sen et al. (2005) found that sodium bicarbonate injection resulted in a better color score.

Injection of SBC to whole trout significantly affected flavor scores and the highest flavor score was obtained using $1 \mathrm{M}$ $\mathrm{SBC}$ injection. The highest texture scores were observed in
$0.75 \mathrm{M}$ and $1 \mathrm{M} \mathrm{SBC}$ injected groups while the lowest texture scores were found in the control, $0.25 \mathrm{M}$ and $0.50 \mathrm{M} \mathrm{SBC}$ injected groups during the iced storage $(p<0.05)$. Similar results have been reported by Åslı and Mørkøre (2012), who observed that higher flavor and firmness scores were obtained with $0.15 \mathrm{M}-\mathrm{NaHCO}_{3}$ treatment compared to the $0.15 \mathrm{M}$ $\mathrm{NaCl}$ treatment and the control. Similarly, Kaufman et al. (1998) found that prerigor $\mathrm{SBC}+\mathrm{NaCl}$ injected samples had improved flavor and juiciness compared with the other treatments.

\section{Chemical quality}

The effects of SBC injections on whole trout $\mathrm{pH}$ values after injection during iced storage are shown in Table 1.

Table 1. Changes in the values of $\mathrm{pH}$ of injected whole rainbow trout during ice storage.

Storage time in ice

\begin{tabular}{|c|c|c|c|c|c|}
\hline \multicolumn{6}{|c|}{ Storage time iा ICe } \\
\hline Hours & Control & $0.25 \mathrm{M}$ & $0.50 \mathrm{M}$ & $0.75 \mathrm{M}$ & $1 \mathrm{M}$ \\
\hline 0 & $6,74 \pm 0.01^{a}$ & $6.81 \pm 0.00^{a}$ & $6.94 \pm 0.05^{b}$ & $6.79 \pm 0.01^{a}$ & $7.00 \pm 0.03^{b}$ \\
\hline 0.5 & $6.04 \pm 0.07 a$ & $6.93 \pm 0.04 b$ & $6.88 \pm 0.04 b$ & $7.07 \pm 0.02^{c}$ & $7.26 \pm 0.06^{d}$ \\
\hline 24 & $6.95 \pm 0.01^{a}$ & $7.07 \pm 0.01^{a}$ & $6.98 \pm 0.01^{a}$ & $7.20 \pm 0.04^{b}$ & $7.43 \pm 0.08^{b}$ \\
\hline \multicolumn{6}{|l|}{ Days } \\
\hline 0 & $6.74 \pm 0.01^{\mathrm{a} 2}$ & $6.81 \pm 0.01^{\mathrm{b} 3}$ & $6.94 \pm 0.05^{c 2}$ & $6.79 \pm 0.01 \mathrm{ab} 1$ & $7.00 \pm 0.03^{\mathrm{d} 1}$ \\
\hline 6 & $6.74 \pm 0.01^{\mathrm{a} 2}$ & $6.91 \pm 0.02^{\mathrm{b} 2}$ & $6.91 \pm 0.02^{\mathrm{b} 2}$ & $7.11 \pm 0.02^{\mathrm{c} 3}$ & $7.14 \pm 0.01 \mathrm{c} 2$ \\
\hline 11 & $6.64 \pm 0.03^{\mathrm{a} 1}$ & $6.62 \pm 0.01^{\mathrm{a} 1}$ & $6.73 \pm 0.01^{\mathrm{b} 1}$ & $6.82 \pm 0.02^{\mathrm{c} 1}$ & $6.93 \pm 0.00 \mathrm{~d} 1$ \\
\hline 16 & $7.08 \pm 0.02^{\mathrm{c} 3}$ & $7.01 \pm 0.03^{b 4}$ & $6.93 \pm 0.04^{\mathrm{a} 2}$ & $6.99 \pm 0.02^{\mathrm{ab} 2}$ & $6.96 \pm 0.04^{a b 1}$ \\
\hline 21 & $7.07 \pm 0.07^{\mathrm{b} 3}$ & $7.02 \pm 0.02^{\mathrm{b} 4}$ & $6.96 \pm 0.01^{\mathrm{a} 2}$ & $7.16 \pm 0.04^{c 3}$ & $7.38 \pm 0.12^{\mathrm{d} 3}$ \\
\hline
\end{tabular}

In early postmortem stage, the effects of SBC injection with different concentrations on muscle $\mathrm{pH}$ just after injection at half an hour (30 min) and 24 hour later were evaluated. There were no significant changes observed in the $\mathrm{pH}$ of whole trout muscle of the control, $0.25 \mathrm{M}$ and $0.75 \mathrm{M} \mathrm{SBC}$ injected groups immediately after injection ( $p>0.05)$, while the $\mathrm{pH}$ value of $0.50 \mathrm{M}$ and $1 \mathrm{M} \mathrm{SBC}$ - injected groups significantly increased $(\mathrm{p}<0.05)$. In one- half hour after injection, the $\mathrm{pH}$ of the SBC-injected groups significantly increased with increasing $\mathrm{SBC}$ concentration and the highest $\mathrm{pH}$ value was obtained with the group injected with 1 M SBC $(p<0.05)$. In the control group, the $\mathrm{pH}$ decreased in one- half hour from 6.74 to 6.04 and then increased to 6.95 after 24 hour storage of ice. According to Huss (1988), the pH decreases mainly owing to anaerobic formation of lactic acid during the first hour after death. If all values analyzed by using general linear model (GLM) to determine concentration effects on $\mathrm{pH}$ values during early post mortem storage, the lowest and highest $\mathrm{pH}$ values were obtained in the control and $1 \mathrm{M} \mathrm{SBC}$-injected group $(p<0.05)$, respectively. Similar results have been found in salted cod fillets by Åslı and Morkore (2012). They observed that SBC injection in lightly salted Atlantic cod muscle caused a pH increase of 0.18-0.33. An increase in the $\mathrm{pH}$ of poultry, pork and beef muscle after SBC injection was also noted by other researchers (Kauffman et al. 1998; Alvarado and Sams, 2002; Sen et al. 2005; Sindelar et al. 2003; Yang et al. 2006).

In four SBC groups, the $\mathrm{pH}$ of the tissues showed a significant decrease at 11 days followed by an increase at 21 days of ice storage $(p<0.05)$. Significant increases were found in the $\mathrm{pH}$ of all groups between initial $\mathrm{pH}$ values and at the end of storage except 0.5 M SBC- injected group, where no significant difference was observed between first and last day of storage $(p>0.05)$.Similarly, an increase in the $\mathrm{pH}$ of hybrid catfish fillets at late post-mortem storage at $4{ }^{\circ} \mathrm{C}$ was found by Chomnawang et al. (2007). Similar observations were also reported by other researchers (Rodriguez et al. 2001; Gimenez et al. 2002; Hultmann and Rustad, 2004). The increase in $\mathrm{pH}$ during the last period of post-mortem storage was postulated to be due to the production of volatile basic components resulting from the breakdown of amines by either endogenous or microbial enzymes (Ruiz-Capillas and Moral, 2001; Benjakul et al. 2002; Hernandez et al.2009).

The effect of SBC injection immediately after harvested on whole trout TVB-N values during ice storage are presented in Table 2. 
Table 2. The changes in TVB-N value of SBC injected groups during ice storage

\begin{tabular}{|l|l|l|l|l|l|}
\hline Storage time in ice & \multicolumn{5}{|c|}{ SBC Concentration } \\
\hline Days & Control & $\mathbf{0 . 2 5} \mathbf{M}$ & $0.50 \mathrm{M}$ & $\mathbf{0 . 7 5} \mathrm{M}$ & $\mathbf{M}$ \\
\hline 0 & $20.68 \pm 1.04^{\mathrm{b} 1}$ & $19.40 \pm 0.86^{\mathrm{b} 2}$ & $20.16 \pm 0.71^{\mathrm{b} 1}$ & $15.70 \pm 1.06^{\mathrm{a} 1}$ & $14.80 \pm 2.08^{\mathrm{a} 1}$ \\
\hline 6 & $20.43 \pm 1.09^{\mathrm{b} 1}$ & $18.82 \pm 0.78^{\mathrm{b} 2}$ & $20.11 \pm 1.26^{\mathrm{b} 1}$ & $18.08 \pm 1.36^{\mathrm{b} 2}$ & $14.62 \pm 1.87^{\mathrm{a} 1}$ \\
\hline 11 & $19.87 \pm 1.92^{\mathrm{b} 1}$ & $17.07 \pm 0.55^{\mathrm{b} 1}$ & $18.50 \pm 1.44^{\mathrm{b} 1}$ & $15.87 \pm 1.61^{\mathrm{a} 1}$ & $14.87 \pm 0.84^{\mathrm{a} 1}$ \\
\hline 16 & - & $20.14 \pm 1.21^{\mathrm{b} 2}$ & $19.03 \pm 1.15^{\mathrm{b} 1}$ & $18.44 \pm 1.05^{\mathrm{b} 2}$ & $15.27 \pm 1.38^{\mathrm{a} 1}$ \\
\hline 21 & $31.17 \pm 2.11^{\mathrm{c} 2}$ & $31.38 \pm 0.62^{\mathrm{c} 3}$ & $21.11 \pm 2.03^{\mathrm{b} 1}$ & $15.47 \pm 0.84^{\mathrm{a} 1}$ & $17.22 \pm 0.92^{\mathrm{a} 2}$ \\
\hline
\end{tabular}

The TVB-N values of the $0.75 \mathrm{M}$ and $1 \mathrm{M} \mathrm{SBC}$-injected groups were significantly lower those that of the other groups at the beginning of the storage $(p<0.05)$. However, 0.25 and $0.50 \mathrm{M} \mathrm{SBC}$ injection did not significantly affect the TVB-N values of whole trout during the early stage of post- mortem storage when compared to the control $(p>0.05)$. TVB-N is one of the most widely used parameters to evaluate fish quality. It consists mainly of mixtures of ammonia, DMA, TMA and others basic nitrogenous compounds.Bacterial deamination of proteins, peptides and also produce TVB-N (Garcia-Garribo and Luque de Castro, 1997). Autolytic breakdown of adenosine monophosphate (AMP) in chilled seafood can also produce TVB-N (Huss, 1995). Benjakul et al. (2003) suggested that some deterioration during handling might cause high levels of TVB-N in fish on the first day of storage. Ethienne (2005) and Mukundan et al. (1986) recommended that the high level of TVB-N at the start of storage might be the result of the amines produced by autolytic processes. Hultmann and Rustad (2004) reported that the changes in TVB-N content during storage may be related to changes in $\mathrm{pH}$. These explanations may account for the lower levels of TVB-N trout injected with the higher SBC levels at the beginning of the storage in the present study and could these might be result of from inhibition of the autolytic processes by the high $\mathrm{pH}$ of the philological fluids in the muscle.

At the end of the storage, TVB-N value significantly increased to $31.2 \mathrm{mg} \mathrm{N} / 100 \mathrm{~g}$ from $20.7 \mathrm{mg} / 100 \mathrm{~g}$ muscle in the control and to $19.4 \mathrm{mg} \mathrm{N} / 100 \mathrm{~g}$ muscle from $31.2 \mathrm{mg} \mathrm{N} /$ $100 \mathrm{~g}$ muscle in the $0.25 \mathrm{M} \mathrm{SBC}$ - injected groups $(\mathrm{p}<0.05)$. The increase in the TVB- $N$ value as the storage time increased agrees with previous results concerning other trout, which nose slowly at the early stage of storage, increasing sharply later on as a result of the activity of microorganisms.
Similar to our findings, Ozogul and Ozogul (2000) observed that no marked increase occurred in the TVB-N level of trout during the early stages of deterioration, while it rose as a result of bacterial activity during the later stages of deterioration. However, there were no significant changes in the $0.50 \mathrm{M}$ and $0.75 \mathrm{M} \mathrm{SBC}$ - injected groups $(p>0.05)$. In the $1 \mathrm{M} \mathrm{SBC}$ injected group, the initial TVB-N value significantly increased to $17.2 \mathrm{mg} \mathrm{N} / 100 \mathrm{~g}$ muscle from $14.8 \mathrm{mg} \mathrm{N} / 100 \mathrm{~g}$ muscle at the end of the storage but this value was still below the initial TVB-N value of the control, $0.25 \mathrm{M}$ and $0.50 \mathrm{M}$ SBC-injected groups. It seems that SBC injection above 0.25 $M$ retards TVB-N production during ice storage.

Many different results have been reported for the TVB-N value of trout during processing, handling and storage. $35 \mathrm{mg}$ $\mathrm{N} / 100 \mathrm{~g}$ TVB-N values in flesh specified by the EC guidelines (Commission Decision 95/149/EC, 1995) for different species of raw fish are generally regarded as the limit of acceptability for ice-stored cold water fish. In contrast, Gimenez et al. (2002) proposed a value of $25 \mathrm{mg} \mathrm{N} / 100 \mathrm{~g}$ of flesh as the highest acceptable level for rainbow trout stored at $1 \pm 1^{\circ} \mathrm{C}$. Similarly, an upper acceptable limit TVBN value of $25 \mathrm{mg}$ $\mathrm{N} / 100$ for rainbow trout was suggested by Arashisar et al. (2004). Chytiri et al. (2004) found no significant differences observed in the TVB-N values of whole trout between the first day (21.2 $\mathrm{mg} \mathrm{N} / 100 \mathrm{~g}$ muscle) and $18^{\text {th }}$. days of storage (20.2 $\mathrm{mg} \mathrm{N} / 100$ ); however there were significant fluctuations in the TVB-N value during iced storage. In this study, no group of trout was rejected by the panelists even though TVB-N level reached to $31.2 \mathrm{mg} \mathrm{N} / 100 \mathrm{~g}$ in control and $31.4 \mathrm{mg} \mathrm{N} / 100 \mathrm{~g}$ in $0.25 \mathrm{M} \mathrm{SBC}$-injected group at the end of the storage.

The effect of SBC injection just after harvested on whole trout SEP values during ice storage are shown in Figure 2. 


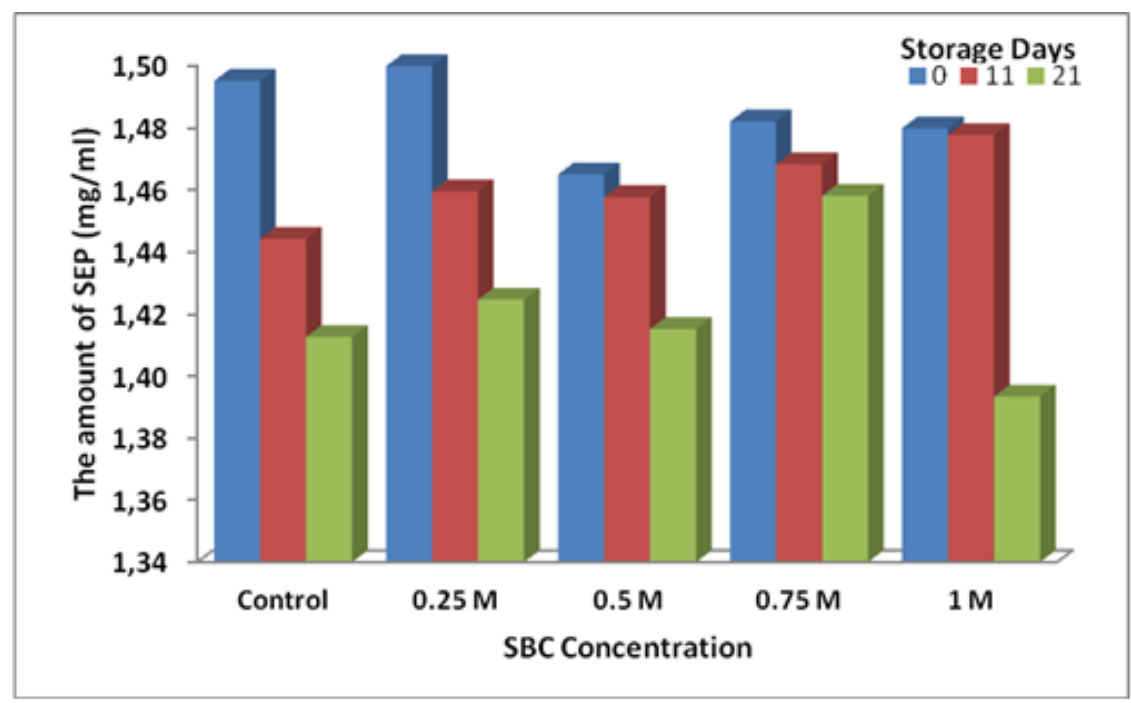

Figure 2. Changes in the amount of salt extractable protein $(\mathrm{mg} / \mathrm{ml})$ of SBC injected whole trout during iced storage.

In this study, the salt-soluble proteins (i.e.,the myofibrillar proteins) have been used to monitor denaturation of myofibrillar protein during ice storage of whole trout injected SBC.A significant decrease in the SEP content was observed in all groups at the end of storage $(p<0.05)$. Similarly, Chomnawang et al. (2007) found the decrease in the saltsoluble protein content of hybrid catfish fillet stored at $4^{\circ} \mathrm{C}$. This decrease was postulated due to the degradation of muscle protein during post- mortem storage associated from the actions of either endogenous or microbial proteinases (Delbarre-Ladrat et al.2006). When compared to the first day of iced storage, SEP values in the control and $0.25 \mathrm{M} \mathrm{SBC}$ injected group significantly $(P<0.05)$ decreased from 1.50 to 1.44 and from 1.50 to 1.46 respectively. $(p<0.05)$, while the SEP content in the $0.50,0.75$ and $1 \mathrm{M} \mathrm{SBC}$-injected groups did not change significantly by day eleven of storage $(p>0.05)$. A significant higher myofibrillar protein following SBC injection into pre-rigor porcine $M$. Longissimuslumborum was also found by Yang et al.(2006). It has been hypotheized that a strong rigor mortis and rapid decline in post-mortem $\mathrm{pH}$ may increase the degree of protein denaturation, thereby increasing the access of substrates to proteolytic enzymes, and causing more rapid softening of flesh (Sigholt, 1997). By day eleven, these groups showed a higher $\mathrm{pH}$ than that of control and the $0.25 \mathrm{M} \mathrm{SBC}$-injected group. These results may help explain why we find a higher SEP content in group injected with the highest concentration of SBC. There were no significant differences between the SEP content of the groups on day 0 ( $p>0.05)$, although significant differences were found between the groups during the storage period $(p<0.05)$. The lowest SEP content was found in the control at day 11 of storage and in the $1 \mathrm{M} \mathrm{SBC}$-injected groups at day 21 of storage $(p<0.05)$, while the highest SEP content were found in $1 \mathrm{M} \mathrm{SBC}$-injected group at day 11 of storage and $0.75 \mathrm{M}$ SBC-injected groups at day $21(p<0.05)$.

Electrophoretic profiles of the salt-soluble proteins extracted with $5 \%(\mathrm{w} / \mathrm{v}) \mathrm{NaCl}$ from trout injected with different concentrations of SBC and stored on ice are shown in Figure 3 .

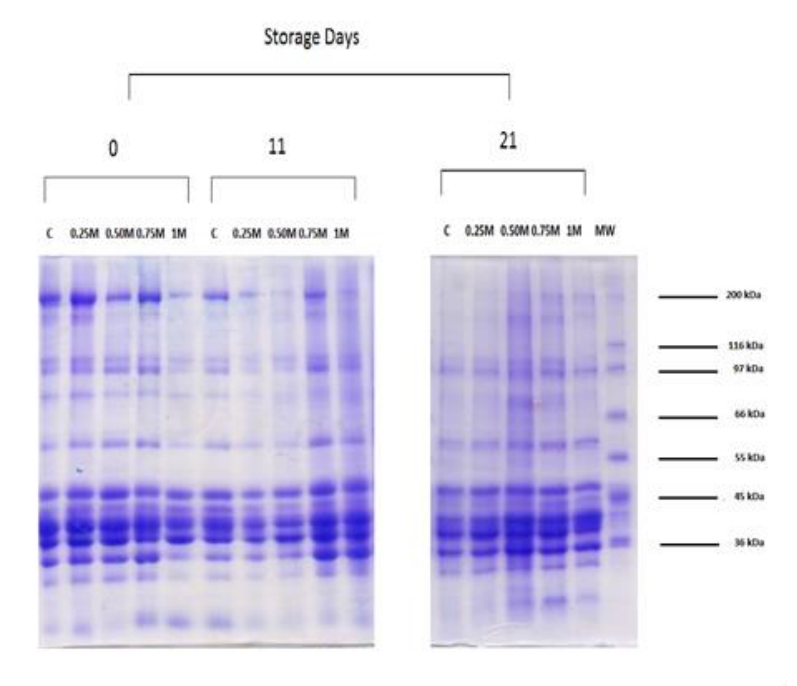

Figure 3. SDS-PAGE patterns of salt soluble proteins $(5 \%, w / v ~ N a C l)$ of whole trout treated with different concentrations of SBC during iced storage. 
at the beginning of storage, major changes in protein bands were evident in the $1 \mathrm{M} \mathrm{SBC}$-injected group;however, many bands disappeared or their intensity decreased.In the $0.5 \mathrm{M}$ SBC-injected group the protein bands below $200 \mathrm{kDa}$ and proteins smaller than $36 \mathrm{kDa}$ (at the bottom of the gel) decrased when compared to the other groups. These results support the obtained results for salt-extractable protein where, although there were no significant differences found between the groups at the beginning of storage, the amount of saltextractable protein in the $0.50 \mathrm{M}$ and $1 \mathrm{M} \mathrm{SBC}$-injected groups were found to be lower. On day 11 , the bands near $200 \mathrm{kDa}$ in the $0.50 \mathrm{M}$ and $1 \mathrm{M}$ SBC-injected groups were barely detectable almost disappeared and the intensity of many bands decreased remarkably in the $0.25 \mathrm{M}, 0.50 \mathrm{M}$ and $1 \mathrm{M}$ SBC-injected groups. In 0.75 M SBC-injected group and later than control, however, the decreases in the intensity of protein bands were seen as very low. At the end of the storage, the bands near $200 \mathrm{kDa}$ and $45 \mathrm{kDa}$ disappeared in the control and $0.25 \mathrm{M} \mathrm{SBC}$-injected groups respectively. In the $0.50 \mathrm{M}$,
$0.75 \mathrm{M}$ and $1 \mathrm{MSBC}$ groups the intensity of this band decreased remarkably. However, Yang et al.(2006) observed no differences in myofibrillar protein fractions between the control and SBC-injected pork in the SDS polyacrylamide gel patterns. The degradation of protein fractions during postmortem storage of fish is known to be caused by proteolytic enzymes acting on muscle cells and connective tissue. In this study, SBC injection at the concentration of $0.5 \mathrm{M}$ and $0.75 \mathrm{M}$ protected against disappearance of the band near $200 \mathrm{kDa}$ at the end of storage.

\section{CONCLUSION}

In conclusion, our data show that whole-trout quality is improved by SBC injection just after slaughter. It was clearly observed that the $0.50 \mathrm{M}$ and $0.75 \mathrm{M} \mathrm{SBC}$ injection caused an increase in $\mathrm{pH}$ level after slaughter, a reduction in TVB-N level and protein denaturation during iced storage. It is suggested that long term in vivo or vitro studies need to be performed to evaluate the effect of SBC injection on quality of trouth.

\section{REFERENCES}

Alvarado, C. Z., Sams,A. R., 2002. The Role Of Carcass Chilling Rate In The Development Of Pale, Exudative Turkey Pectoralis. Poultry Science, 81:1365- 1370. doi:10.1093/ps/81.9.1365

Antonacopoulos, N., 1973. In: Fische und Fischerzeugnisse. W. Ludorff and V. Meyer (eds) Paul Parey, Berlin, pp.224-225.

Arashisar, S., Hisar, O., Kaya, M., Yanik, T. 2004. Effects of modified atmosphere and vacuum packaging on microbiological and chemical properties of rainbow trout (Oncorhynchus mykiss) fillets. Internationa Journal of Food Microbiology, 97: 209-214 doi:10.1016/j.ijfoodmicro.2004.05.024

Åslı, M., Mørkøre, T., 2012. Brines Added Sodium Bicarbonate Improve Liquid Retention and Sensory Attributes of Lightly Salted Atlantic Cod. LWT - Food Science Science. and Technology, 4: 196-202. doi: 10.1016/j.lwt.2011.10.007

Bertram, H.C., Rikke, L.M., Zhiyun, W., Xingfei, Z., Henrik, J.A., 2008. Water Distribu-tion and Microstructurein Enhanced Pork. Journal of Agricutural and Food Chemisrty, 56: 7201- 7207. doi: 10.1021/jf8007426

Benjakul, S., Visessanguan, W., Rie broy, S., Ishizaki, S., Tanaka, M., 2002 Gelforming properties of surimi produced from bigeye snapper Priacanthus tayenus and P. macracanthus, stored in ice. Journal of the Science of Food and Agriculture, 82:1442-1451. doi:10.1002/jsfa.1207

Benjakul, S., Visessanguan, W, Tueksuban J., 2003. Changes in physicochemical properties and gel-forming ability of lizardfish (Saurida tumbil) during post-mortem storage in ice. Food Chemistry, 80: 535-544. doi: 10.1016/S0308-8146(02)00339-4

Chomnawang, C., Nantachai, K., Yongsawatdigul, J., Thawornchinsobut, S. Tungk-awachara, S. 2007. Chemical and biochemical changes of hybrid catfish fillet stored at $4^{\circ} \mathrm{C}$ and its gel properties. Food Chemistry,103:420-427. doi: 10.1016/j.foodchem.2006.07.039

Corral,L.G., Post,L. S., Montville, T.J., 2006. Antimicrobial Activity of Sodium Bicarbonate. Journal of Food Science, 53: 981 - 998. doi: 10.1111/j.13-62621.1988.tb09005.x

Chytiri, S., Paleologos, E., Savvaidis, I., Kontaminas, Mg., 2004.Relation of Biogenic Amines with Microbial and Sensory Changes of Whole and Filleted Freshwater Rainbow Trout (Oncorynchus Mykiss) Stored on İce. Journal of Food Protection, 67(5):960-5.

Delbarre-Ladrat, C., Che'Ret, R., Taylor, R., Verrez-Bagnıs, V., 2006 .Trends in Postmortem Aging in Fish.Understanding of Proteolysis and Disorganization of The Myofibrillar Structure. Critical Reviews in Food Science and Nutrition, 46: 409-421. doi: 10.1080/10408390591000929

Dyer, W. J., H.V. French, Snow. J.M., 1950. Proteins in Fish muscle. (1) Extraction of protein fraction in fresh fish.Journal of the Fisheries Research Board of Canada, 7: 585-593.doi:10.1139/f47-052

Etienne., M.2005. Seafood plus - Traceability - Valid -Methods for chemical quality assessment. Volatile amines as criteria for chemical quality assessment, Ifremer, Nantes, France. Available online: http://archimer.ifremer.fr/doc/2005/rapport-6486.pdf (accessedFebruary 2011).

Garcia-Garrido J.A., Luque de Castro M.D., 1997. Determination of trimethylamine in fish by pervaporation and photometric detection. Analyst. 122 (7): 663-666 doi: 10.1039/A700547D

Gımınez, B., Roncales, R., Beltran, J.A., 2002. Modified Atmosphere Packaging of Filleted Rainbow Trout. Journal of the Science of Food and Agriculture, 82:1154-1159. doi:10.1002/jsfa.1136

Hernandez, M.D., Lopez, M.B., Alvarez, A., Ferrandini, E., Garcia, B., Garrido, M D., 2009. Sensory, physical, chemical and microbiological changes in aquacultured meagre (Argyrosomus regius) fillets during ice storage. Food Chemistry, 114: 237-245. doi: 10.1016/j.foodchem.2008.09.045

Hultmann, L., Rustad, T., 2004. Iced storage of Atlantic salmon (Salmo salar) effects on endogenous enzymes and their impact on muscle portions and texture. Food Chemistry. 8:, 31-41.

doi:10.1016/j.foodchem.2003.10.013

Huss, H.H., 1988 .Fresh fish- quality and quality changes. Training ManualRome: United Nations. Food and Agriculture Organization of the United Nations Danish International Development Agency: FAO/DANIDA

Huss H.H., 1995. Quality and quality changes in fresh fish. FAO Fisheries Technical Paper 348, FAO. 
Kauffman, R.G., Vanlacck, R.L.J.M., Russel, R.L., Pospiech, E., Corneli S,C.A., Suckow, C.E., Greaser, M.L., 1998. Can Pale, Soft, Exudative Pork be Prevented by Postmortem Sodium Bicarbonate Injection? Journal of Animal Science, 76: 3010-3015

Laemmli, U. K. 1970. Cleavage of structural proteins during assembly of the head of bacteriophage T4. Nature, 227 (5259): 680-685.

Lowry, O.H., Rosebrough, N.J., Farr, A.L., Randall, R.J., 1951. Protein Measurement with the Folin Phenol Reagent. Journal of Biological Chemistry, 193: 265-275.

Mukundan, M. K., Antony, P.D., Nair, M.R., 1986. A review on autolysis in fish. In Fisheries Research, 4: 259-269. doi: 10.1016/0165-7836(86)90007-X

Paulus, K., Zacharias, R., Robinson, L., Geidel, H., 1979. Kritische betrachtungen zur "Bewetenden prüfung mit skale" als Einem Wesentlichen Verfahren der Sensorich-en Analyse. LWT. 12(1): 52-61.

Rodriguez-G M-N, Sanz Jj, Santos Ja, Otero A, Lopez-G M-L., 2001 Bacteriological Quality of Aquacultured Fresh Water Fish Portions in Prepackaged Trays Stored at $3^{\circ} \mathrm{C}$. Journal of Food Protection, 64(9): $1399-1404$.

Ruiz-Capillas, C., Moral, A., 2001. Correlation between biochemical and sensory quality indices in hake stored in ice. Journal of Food Science,34: 441-447. doi: 10.1016/S0963-9969(00)00189-7

Offer G., Trinick J., 1983. On the Mechanism of Water Holding in Meat:The swelling and shrinking of myofibrils. Meat Science, 80:245-281. doi: 10.1016/0309-1740(83)90013-X
Ozogul, F., Ozogul, Y., 2000. Comparisons of methods used for determination of volatile basic nitrogen (TVB-N) in Rainbow trout (Oncorhyncus mykiss). Turkish Journal of Zoology. 24: 113-120.

Sen, A.R., Naveena, B.M., Muthukumar, M., Babji, Y., Murthy, T.R.K., 2005. Effect of Chilling, Polyphosphate and Bicarbonate on Quality Characteristics of Broiler Breast Meat British Poultry Science, 46: 451456. doi:10.1080/00071660500191072

Sigholt,T., Erikson,U., Rustad,T., Johansen,S., Nordtvedt,T.S., Seland, A., 1997. Handlingstress and storage temperature affect meat quality of farmed raised Atlantic salmon (Salmo salar). Journal of Food Science, 62(4): 898-905. doi: 10.1111/j.1365-2621.1997.tb15482.x

Sindelar, J. J., Prochaska, F., Britt, J. Smith, G.L., Miller, R.K., Templeman, R., Osburn, W.N., 2003. Strategies to eliminate atypical flavours and aromas in sow loins. 1. Optimization of sodium tripolyphosphate, sodium bicarbonate, and injection level. Meat Science, 65:1211- 1222.

doi: 10.1016/S0309-1740(03)00027-5

TUIK, 2011. "GDP" and "Foreign Trade by Years". http://www.tuik.gov.tr. [Accessed: 19.11.2012].

Yang, H.S., Moon, S.S., Jeong, J.Y., Choi, S.G., Joo , S.T., Park. G.B., 2006 Effect of sodium bicarbonate injection in pre-rigor porcine $M$. Longissimus lumborum on pork quality. Asia-Aust.Jornal of Animal Science,19:898-904.

Whyneen, E.J., Bowker, A.L., Grant, A. L., Lamkey, J.M., Fennewalk,K.J., Henson, L., Gerrard, D.E., 2001.Pork quality is affected by early postmortem phosphate and bicarbonate injection. Journal of Food Science, 66: 886-891.doi: 10.1111/j.1365-2621.2001.tb15191.x 